\title{
Protagonist and Choice of Digitalization of Administration Amenities in Rightful and Viable Change of Country Finances
}

\author{
A. Jayabal
}

\begin{abstract}
With the advent of internet at the start of the century to the recent change, internet of things ie; digitalisation and integration of infrastructure, has proven itself to enhance social and economic productivity. Amongst these technological advancements, country finances lagged behind which includes majority of human populous. Recently global economy faced slump despite thee advancement. The need of the art is to enhance and enrich country finances and bring them to terms with global standards and practices. This could be done by giving country finances impetus by providing knowledge of global scenarios i.e.; democratization of the country economy. Country finances are environment friendly by and large, therefore sustainable. Thus, there is need of developing technology central country economy which promotes micro and small enterprises, exploring new avenues for them and world for sustainable devotement. This initiative could bring substantial change to eliminate multi-dimensional poverty in the world, especially SAARC countries. In the light of aforementioned fax, the study tries to focus on role of digitization of administration services to bring the country finances, especially SAARC countries into world economy grid. An attempt also to explore the various benefits it had bring to country finances of the SAARC region along with the new frontiers that the digitalisation has opened for country finances to conquer.
\end{abstract}

Keywords: Digital, Country Finances and Administrations.

\section{INTRODUCTION}

The change of country finances is the need of the hour for comprehensive growth of global economy. A significant proportion of world's population is still dependent on country economy, specially the third world finances which are driven by country finances; this is true especially for SAARC countries.

For the change of any local economy it needs to be linked to other o finances that finances that exist, this has become a fact in the era of globalised business. To have this change inter-connectivity could be solved by a modern technology named digitalization, whereby this digital format can be remitted or transferred or transmitted to other businesses that are in the need of the information. The information is very often transmitted to the remotest country areas where there is an information deficit.

Revised Manuscript Received on December 05, 2019.

* Correspondence Author

Dr. A. Jayabal*, HOD, Department of Commerce, SRM, IST, Ramapuram Campus, SRM University, Chennai, India.
The main reason is lagging of country finances is the lack of country finances is the lack of administration infrastructure in the country and remote areas. It cannot be said with great reliability that is due to lack of policy making or lacks in implementation of policies. To overcome these hurdles the administration needs to step up and ensure proper infrastructure for digitalization. $\mathrm{O}$ initiates connectivity across the country finances; administrations must step-up and start with digitalization of its own services to encourage finances.

In the recent times, mobile and mobile data packs are the new technological innovations that can be used against hurdles of ICT (Information, Communication and Technology) an UNDO mission. As $10 \%$ increases in internet connections have shown to expand the economy by $1.3 \%$ (World Bank, 2009). Digitalizations of administration services are also required so that the huge information deficit could be fulfilled and help decrease the offer and demand disparity. This in turn will ensure booming of country finances and help them come to terms with the global economy. This could help make an equitable and sustainable country economy.

\section{BACKGROUND}

Country finances have been in the Indian sub-continent, since the ancient times that date to about 1500 B.C, in the Indus valley civilisation. Since the Indus valley civilisation many civilizations have come and gone, many regimes have changed, but to date country finances still exist despite the tough times they had to use. Now the time is right to lay emphasis and empower these finances to terms with the global economy.

A factor that has been most influential in the change of economy is information. We are in the information age, now so it is the right of the country finances as well to have equal access to the information, whichever they may need. UNDP has formed special cell for this purpose ICT (Information, Communication and Technology) in the year 2009.

Earlier before the ICT programme also various administrations have stated to digitalize their services and environment to promote their finances to grow, but in this quest, they left a major proportion of the populous behind that is country finances. For this SAARC member nations took a pledge to digitalise information for country finances, i.e.; CIRDAP (Centre

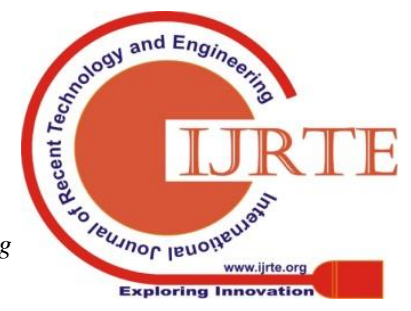


on Integrated Country Change of Asia and the Pacific).

This paper focuses on the various schemes run by the various SAARC members for digitalization of their services, their roles as well as their scope for the change of an equitable and sustainable country economic environment so that, they can help in eradication of multi-dimensional poverty in the region. Now we will discuss a few important projects done by member nations to help digitalize and develop administration services for country finances.

\section{Various Projects of SAARC Member Nations}

There are eight member countries in SAARC and we will be discussing each of them separately.

Afghanistan: Afghanistan is a land locked country and the eastern most member nation of SAARC. It had been torn by Taliban in the past, but now it is on track of fast pace change. The two major projects held here for digitalization are: -

- GEP ii (Gender Equality Projects): The project is run by the UNDP for the women of Afghanistan. It aims at education for women and also aims to provide employment opportunities to women. This county has also institutes the representations towards the administration cooperation and coordination, the Government along with NGOs and other civil society associates are inciting gender into the mainstreaming of the society. This would enable them to provide a better position to women, this would be possible upon giving trainings to women into the business world and to go to other countries to get an first-hand information towards their development and strengthen the position of women. It creates women entrepreneurs by providing training on how to set up, operate and market a business, including study visits to successful businesses in other provinces and neighboring countries. GEP has been a successful project for Afghanistan as it has created an online database program termed NAPWA which is called as National Action Plan for Women in Afghanistan and a project sponsored by German government of Economic Cooperation and change.

- These two countries both Afghanistan and Germany have agreed on the development in the areas of priority like water resources, education, energy, emergency and transitional aid, health Governance and Civil Peace services.

Bangladesh: it is the western most member nation of SAARC, with the most population density and also the most faced digitization programs, with a target to be fully digitizes by the year 2021, under the name digital Bangladesh. A few of the initiatives are mentioned below

- NESS (National E-Services System): this is an initiative $\mathrm{t}$ administration for providing e services with certain limits. The NESS accommodates the services provided by the administration. To its people. e service under this system has a capacity to go for online services and also to establish the mobile based applications.

- UISC (Union Information and Service Centre) is a Centre for the for services at single end, a newly formed centre having outlets which established at all Union and local administrations, which are called as Union Parishads means local administration at the lower level. These centres are using ICT, Union Digital centre facility to provide services to the people at their doorstep, these are centres run by entrepreneurs who are in the local areas. supported by central administration and UP's.

Bhutan: Bhutan is a landlocked state between India, Nepal and china. It is one of the member nations of SAARC and also carrying on many digitalization projects like:

- Administration intranet: it has security and speedy network which connects the all the department of the Government including the, Prime minister's office and other administration organizations in the capital city Thimphu and Dzongkhag administration. Thimphu wide Area Network (TWAN) is the core network that connects all the administration programmes. These help the process of interconnectivity of all the ministries for the development of the country's economy.

India: India is the most populous and the largest country amongst the SAARC member nations. It has led a way with the tagline digital India to promote digitalization in the sub-continent. Some of the projects for this are mentioned below

- $\quad$ E-filing Portal: the portal for the National Governance Plan of the administration. It aims at providing the portal at a single window access to the information and services by the Indian Administration for the citizens.

- DBT (Direct Benefits Transfer): DBT transfers the subsidies provided by the Government and it was launched on 1stJanuary 2013. It focuses at the transfer subsidies directly to people in their bank accounts.

- Start-Up India: This campaign for promoting finance given by banks for start-up ventures to encourage entrepreneurship in the country. The easy for getting license and remove any hindrances regards land permissions, investment, environmental clearances. Funding are available for change and refinancing and refinancing the start-ups as micro units with a refinance fund of Rs. 200 billion.

Nepal: Nepal is a land locked country in the Indian sub-continent, which is working fast in the field of digitalisation to expand its economy.

- Country E-Community: it is a project undertaken by Nepal to connect all of its country communities amongst themselves as well as the world. This in turn will ensure free flow of information and help the country communities grow. 
Pakistan: it is located in the south west of the Indian subcontinent and the origins of Indus valley civilizations are found here. Many of the digitalization programmes are still in their infancy here but a single one that stands out is the NADRA (National Advanced Database Registration Authority) which introduced the Smart National Identity cards Pakistan's first national electronic identity card and used for voting purpose and for pensions, social and financial inclusion programmes.

Sri Lanka: as island nation South Asia, Sri Lanka has a literacy rate of over $90 \%$, which is one of the highest regions. Some of the projects in this context are:

- $\quad$ E-Srilanka: Sri Lanka has launched 'E-Sri Lanka”, of using ICT to fulfill the social integration and economic growth including and poverty eradication.

- $\quad \boldsymbol{E}$-HRM: e-HRM is any technology that is used in order to attract talented, workforce for administration, and optimize workforce management. The new trend is towards the self-service intranets, most probably using web-based technology. It is evident that with the emergence of e-HRM, human resource management has become a strategic tool than a function. These systems were expected to improve the performance of any business organization whether country or urban, this project is deployed by Sri Lanka.

- Automated Taxation: it is a process in which the users can pay tax online, without much hassled of going to the tax office to file their tax. This beneficial for the country businesses as they can save huge amount of time that can be used in much productive works.

\section{CONCLUSION}

Digitization is being used to tackle information deficiency in country and remote areas. In this paper I tried to outline some of the major digitization projects that are taken up by various SAARC member nations. It could be said that digitization of the administration services is still in its infancy yet going strong. The administrations have put in their best efforts to percolate the information to the lowest strata of the society so that an integrated economy could be developed on the back of country economy. This would help in equitable and sustainable change of country finances. Certain limitations of this paper are that still many projects are still in infancy and nothing can be said certainly at this point. Secondly only few major projects are taken on country basis. So, future researches can be done by working on these limitations.

\section{REFERENCES}

1. Centre on integrated countrychange for Asia and the pacific (CIRDAP). Retrieved April 15, 2016,

2. Digital India programme | department of electronics and information technology, govt of India. 15,April 2016.

3. Securities and exchange commission of PakistanRetrieved April 15, 2016, http://eservices.secp.gov.pk/eservices/

\author{
4. Gender Equality Project (GEP II). (n.d.) 2016 \\ http://www.af.undp.org/content/afganishtan \\ home/operations/projects/womens_ii.html \\ 5. People's Primary Healthcare InitiativeApril 15, 2016, from \\ http://www.pphi.org \\ 6. http://www.eservice.gov.bd. \\ 7. Bhutan Portal, Aprilhttp://www.bhutan.gov.bt \\ 8. Service Innovation Fund (SIF) (n.d.) April 2016, from http://www.a2i.p
}

\section{AUTHOR PROFILE}

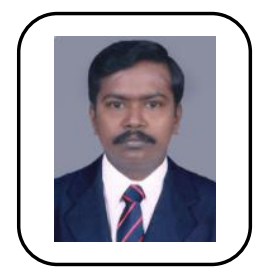

A. Jayabal, M.Com (MadrasUniversity), M.Phil (Periyar University) and B.ed (Madras University), $\mathrm{Ph} . \mathrm{D}$ (University of Madras)is an Asst.Professor in the faculty of finance at SRM, Institute of Science \& Technology, Ramapuram, Chennai andhe worked as a Asst. professor in the faculty of finance at GaedduCollegeofBusiness Studies,theRoyalUniversityof Bhutan.Duringhis 26yearsasanacademic and corporate,Jayabaltaught Working Capital management, Introduction to Corporate Finance and Financial management, Introduction to Financial Accounting and Auditing, Business Management, Company Law \& Secretarial Practice, Business law, Income Tax.Jayabalhascontributedtoover10publications includingbookchapters, peerreviewedjournalarticlesandconferenceproceedings. Jayabalworkedforthe Care Indiaas co-coordinatorpriortouniversityteaching.Hiscurrentresearch interestsarein Finance and Micro-Finance-SHG's related behavioralandsocietyandbusinessinterface.

Working as a Head \&Professor- SRM,IST, Ramapuram, Chennai- July 2018- Till Date.

Working as a Asst.Professor- Gaedu College of Business Studies, RUB, Gedu, Chukha , Bhutan- June 2010- June 2015.

$\square$ Worked as a Program Associate \& Finance Coordinator - CARE India, (Chennai \& Andaman) - November 2005- May 2010.

$\checkmark$ Worked as a Manager - Loss Prevention (Auditor) M/s. Subhiksha Trading Private Ltd., Chennai - January 2005 to June 2005.

Worked as a Administrative \& Accounts Manager- Indian School Ibra, Ibra, Sultanate of Oman- December 2000 to October 2004

$\square$ Worked as aLecturer - United College of Arts and Science,Andaman- May 1994 to Nov 2000. 